\title{
Seasonal variability of water quality and metazooplankton community structure in Xiaowan Reservoir of the upper Mekong River
}

\author{
Xiaodong WU,, $2^{*}$ Daming HE, ${ }^{2}$ Guijun YANG,${ }^{3}$ Linlin YE, ${ }^{4}$ Chunling ZHU, ${ }^{2}$ Haifeng JIA, ${ }^{2}$ Jinming $\mathrm{HU}^{2 *}$ \\ ${ }^{1}$ Cryosphere Research Station on the Qinghai-Tibetan Plateau, State Key Laboratory of Cryospheric Sciences, Cold and Arid Regions \\ Environmental and Engineering Research Institute, Chinese Academy of Sciences, 320 West Donggang Road, 730000 Lanzhou, \\ China; ${ }^{2}$ Asian International Rivers Center, Yunnan Key Lab of International Rivers and Transboundary Eco-security, Yunnan University, \\ 2 North Road of Green Lake, 650091 Kunming, China; ${ }^{3}$ School of Environmental and Civil Engineering, Jiangnan University, 1800 \\ Lihu Road, 214122 Wuxi, China; ${ }^{4}$ School of Geography Science, Nantong University, 999 East Waihuan Road, Nantong 226019, China \\ *Corresponding authors: wxd565@163.com (X.Wu) or jhuynu@163.com (J.Hu)
}

\begin{abstract}
Water quality problems in the Xiaowan Reservoir due to a recently built dam of upper Mekong River have became major ecological and economic concerns. The main goal of this work was thus to describe the present water quality and metazooplankton dynamics and to evaluate the effects of damming on aquatic ecosystem in the super reservoir. The water quality including conductivity, turbidity, Chlorophyll a, dissolved oxygen, total nitrogen, total phosphorus and metazooplankton communities were surveyed along the $30 \mathrm{~km}$ away from the dam in the reservoir from 2011 to 2012. Throughout our study, most of the water quality parameters showed clear temporal changes. The total nitrogen and phosphorus showed mean values of 0.9 and $0.04 \mathrm{mg} \mathrm{L}^{-1}$ at different sites. The dominated species of zooplankton showed typical seasonal succession. The most important factor in the determination of zooplankton throughout the year is water temperature and Chlorophyll a. The spatial distribution of water quality parameters and zooplankton communities fluctuated considerably among different sites. However, it is difficult to explain these spatial changes which may relate to the unstable water conditions. Our results showed that the area along the $30 \mathrm{~km}$ away from the dam of Xiaowan Reservoir belonged to lake-type environment. More attention should be paid on the aquatic ecosystems of the reservoirs which belong to the gorge area with high mountains and steep valleys.
\end{abstract}

Key words: upper Mekong River, dam construction, Xiaowan Reservoir, metazooplankton, nutrients content.

Received: May 2013. Accepted: October 2013.

\section{INTRODUCTION}

Although large reservoirs play an important role in promoting economic and social development and provide important services such as electricity generation, water supplies, flood control, assistant navigation, it has been well known that dam construction will affect the flow velocity, water temperature, sediments delivery, dissolved oxygen, water level, salinity of river systems, and aquatic ecosystems. During the past decades, many studies have focused on the effects of dam construction on the water environment and aquatic ecosystems (Karr, 1991; Nilsson and Berggren, 2000).

Mekong River is the sixth largest river in the world. It contains a large number of endemic species, and overall high level of biodiversity. The upstream of the upper Mekong River has an average gradient of $1.5 \%$ and the middle and the downstream from $0.8 \%$ to $1 \%$ so the river has a huge potential energy by electricity output. Nowadays, there have been two completed hydropower dams (Manwan dam and Dachaoshan dam) on the middle reach of the Lancang River as well as several more dams and storage reservoirs for hydropower production under con- struction and in planning (Wei et al., 2009). Since Mekong River plays an extremely important role in the economic and social development of China, Myanmar, Laos, Thailand, Vietnam and Cambodia, the issue of dam construction on Mekong River has became a major ecological concern in these countries. So far, the studies have been performed mainly focused on hydrology, water resources, and sediments (He et al., 2006). As for the ecoenvironment of the upper Mekong River, only a few reports considered the fish (Kang et al., 2009), nutrients distribution (Wei et al., 2009) and phytoplankton (Wang et al., 2004).

Xiaowan power station is the second power station in the planned eight dams. The reservoir covers an area of $189.1 \mathrm{Km}^{2}$. The Xiaowan hydropower construction began in October 2004 and water began to fill the reservoir on December 2008. Such a large dam must have important effects on the ecosystems of upper Mekong River. However, the potential effects of reservoir on the aquatic ecosystems are still relatively unexplored in this important international river. Although there were some studies on other reservoirs such as Three-Gorge Reservoir, it is dif- 
ficult to apply these results in the upper Mekong River since the reservoirs in upper Mekong River belong to the gorge area with high mountains and steep valleys.

Zooplankton are widely distributed organisms in freshwater lakes, they are consumers of phytoplankton, and are also the main prey of fish especially the planktivorous fish (Scheffer, 1999). Zooplankton are sensitive to environmental factors such as nutrients, depths, current velocity, $\mathrm{pH}$, salinity, dissolved oxygen (Kelderman, 1984; Schulz and Sterner, 1999; Bigler et al., 2006; Plath and Boersma, 2001). Therefore, they are useful indicators to assess the effects of reservoir construction on aquatic ecosystems (Humborg et al., 1997; Lancelot et al., 2002; Nogueira, 2001). The present study will investigate the temporal and spatial patterns of zooplankton in Xiaowan Reservoir, and the possible factors that may relate to these spatial and temporal variations will be interpreted. The results will offer some insight into the aquatic ecosystems response to the dam construction in this international river, as well as provide ecological datasets for further modelling studies.

\section{METHODS}

\section{Reservoir description}

The upper Mekong River flows to the South China Sea along the south and east directions crossing six nations. This international river has a total length of 4880 $\mathrm{km}$ from the headwaters to its mouth and nearly half flows through Yunnan Province in China. Xiaowan hydropower station, with an installed capacity of $4200 \mathrm{MW}$, is located in the middle reach of upper Mekong River. The backwater of upper Mekong River is $178 \mathrm{~km}$, with a tributary of Heihui River (Fig. 1). Most of the mountain peaks nearby the reservoir are higher than $2200 \mathrm{~m}$ above sea level. The reservoir climate belongs to subtropical low latitude mountain monsoon climate, with an annual average temperature of $19^{\circ} \mathrm{C}$ in the valley, and about $10^{\circ} \mathrm{C}$ in the mountainous area on the top of the slope. The total storage capacity of Xiaowan Reservoir is about $150 \times 10^{8} \mathrm{~m}^{3}$, with a dam height of $292 \mathrm{~m}$.

\section{Field sampling}

Fieldwork was undertaken from September 2011 to September 2012. The samples were collected monthly expect for December 2011 and May 2012. Five sites were selected along the $30 \mathrm{~km}$ away from the dam (Fig. 1). The water samples were collected at depths of $0.5 \mathrm{~m}$. Water temperature, conductivity, turbidity, dissolved oxygen (DO) were measured with a multi-parameter water quality sonde 6600 (Yellow Spring Instruments, Yellow Springs, $\mathrm{OH}, \mathrm{USA}$ ). Total nitrogen (TN) and total phosphorus (TP) were analyzed by the Chinese standard methods for Lake Eutrophication surveys (Jin and Tu, 1990). Three replicate measurements of subsamples from each sample were performed. Chl- $a$ was collected on a GF/C filter and extracted with $90 \%$ acetone was measured using the method

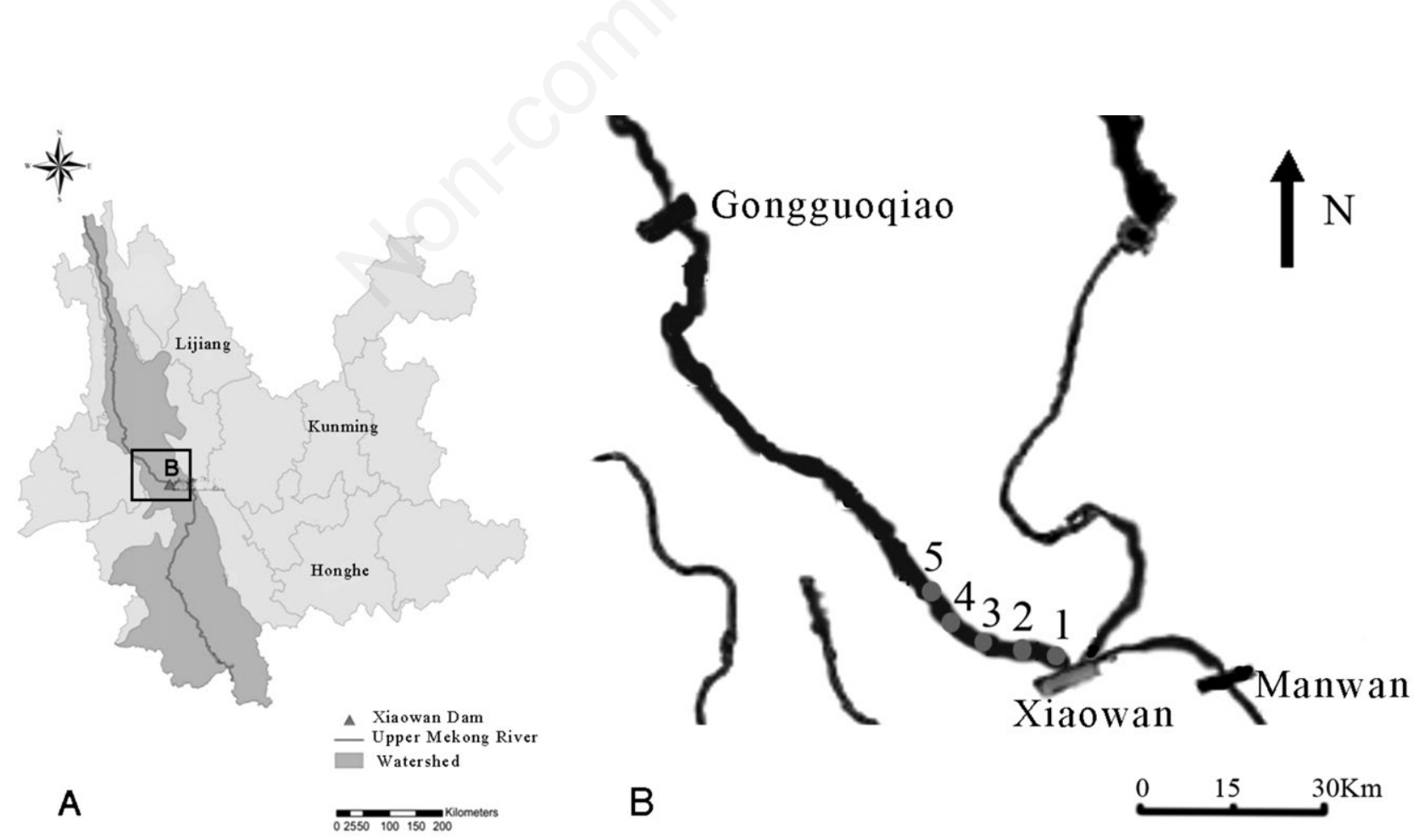

Fig. 1. The upper Mekong River watershed in Yunnan Province (A) and the sampling sites in Xiaowan Reservoir (B). 
described by Ye et al. (2012). Metazooplankton samplings were collected using plankton nets of 40 and $60 \mu \mathrm{m}$ mesh for rotifers and crustaceans, respectively, through vertical hauls of the entire water column. Twenty $\mathrm{L}$ water samples were collected and filter to $30 \mathrm{~mL}$ by $40 \mu \mathrm{m}$ mesh for quantitative analysis of zooplankton. The samples were fixed with formaldehyde to a final concentration of approximately $4 \%$. Zooplankton was counted and identified microscopically in a counting chamber according to the procedures described in Harris et al. (2000). The zooplankton were identified to species based on the Methods for Freshwater Plankton (Zhang and Huang, 1991) and the Fauna Sinica (Jiang and Du, 1979). All taxa were identified down to the lowest possible taxonomic level.

\section{Statistical analysis}

Data in the present study were presented as mean \pm SD. Statistical analysis was performed using SPSS 14.0. Zooplankton communities and environment relations were studied using CANOCO software version 4.5 (Biometris, Wageningen, The Netherlands). A preliminary detrended correspondence analysis (DCA) with detrending by segments showed that the values of extracted gradient lengths in the data were always less than 4 standard deviation units (Ter Braak and Smilauer, 2002). Linear responses are expected along such a gradient, and the constraining ordination method used was redundancy analysis (RDA). The contour maps were produced using Surfer 8.0 with the Kriging method. The other figures were produced using Origin 8.0.

\section{RESULTS}

\section{Water quality in the reservoir}

The physical parameters at the five sampling site are shown in Fig. 2. The water temperature varied from 17.1 to $28.2^{\circ} \mathrm{C}$ with the maximum value in September 2011 and the minimum value in February 2012 (Fig. 2a). The dissolved oxygen fluctuated during the sampling period, ranging from 5.5 to $9.2 \mathrm{mg} \mathrm{L}^{-1}$ (Fig. 2b). The conductivity varied from 0.28 to $0.37 \mathrm{mS} \mathrm{cm}^{-1}$. From October 2011 to March 2012, the conductivity generally decreased with the distance from the Xiaowan dam. In the July and August 2012, the conductivity increased with the distance from the dam. In the spring and autumn, the differences of the conductivity among the five sampling sites were less obvious (Fig. 3a). The sampling area in the reservoir is in clear water state, and the turbidity varied between 0.01 and $6.95 \mathrm{Ntu}$. The turbidity was higher from April to August and showed lower values from September to March. The highest turbidity was recorded at the site 1 in June 2012 (Fig. 3b). The Chl- $a$ undergone typical seasonal changes characterized by a clear decrease during autumn and winter following an increase during spring and summer. The highest Chl- $a$ content appeared in June at site 4 with the value of $10.9 \mu \mathrm{g} \mathrm{L}^{-1}$ (Fig. 3c). The total nitrogen and total phosphorus contents are shown in Fig. 4. The TN contents were relatively higher during November to March at the five sites, which were similar to the conductivity. The total phosphorus content varied from 0.02 to $0.06 \mathrm{mg} \mathrm{L}^{-1}$, with a mean value of $0.04 \mathrm{mg} \mathrm{L}^{-1}$. The total phosphorus decreased from October to February and then gradually increased from much to July.

In order to reveal the relationship between the measured water quality parameters, the variations of the water quality parameters were evaluated correlation matrix using the Spearman non-parametric correlation coefficient (Spearman's R). The correlation matrix was shown in Tab.1. Some clear hydrochemical relationships can be readily inferred: Significantly positive correlation can be observed between temperature, TP, Chl- $a$ and turbidity, while the TN significantly negative correlated with TP, temperature and turbidity.
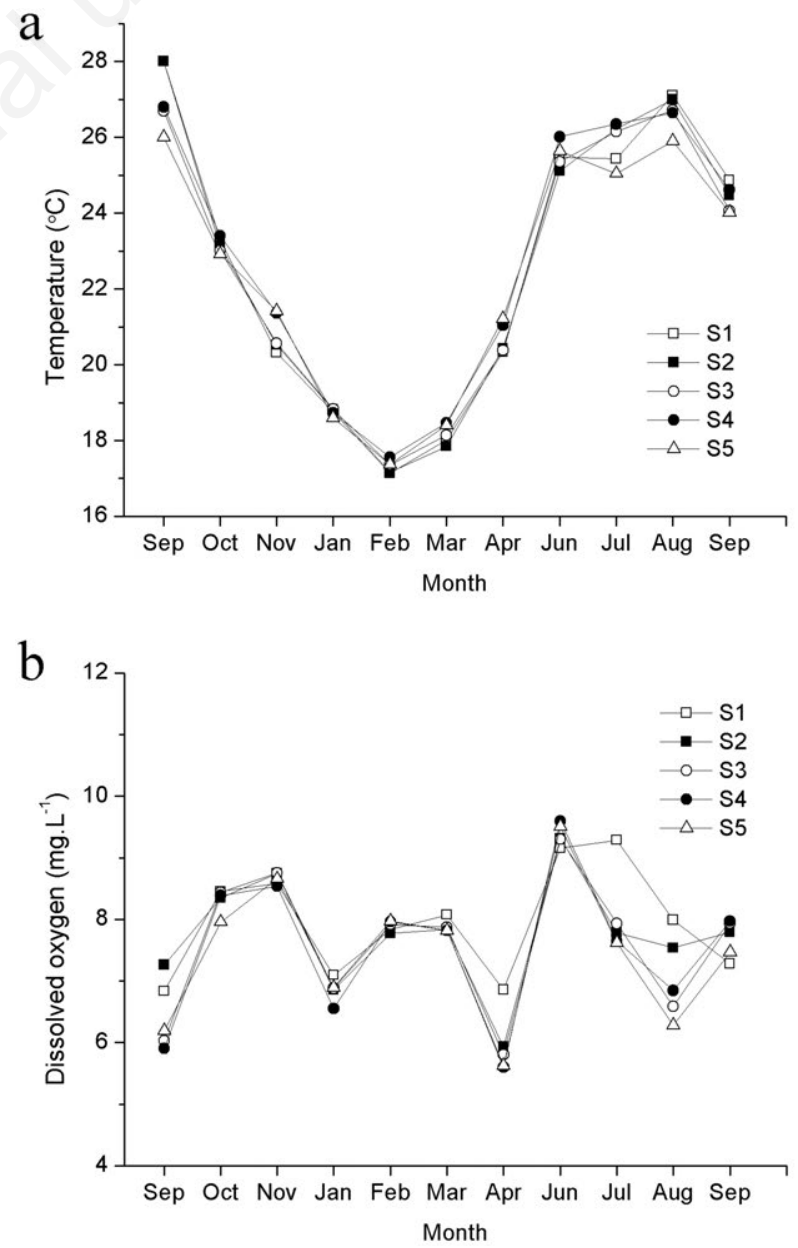

Fig. 2. Temporal variations of temperature (a) and dissolved oxygen (b), at different sites. 


\section{Zooplankton structure}

In the reservoir, zooplankton can reach high values about 600 ind. $\mathrm{L}^{-1}, 4 \mathrm{mg} \mathrm{L}^{-1}$. The species of zooplankton recorded at different sampling periods were shown in Tab. 2. The principal microcrustacean species include copepds (mostly nauplius, Microcyclops varicans, Mesocyclops leuckarti, Limnoithona sinensis, Schmackeria inopinus), and cladocerans (Bosmina coregoni, Daphnia hyalina, Daphnia pulex, Diaphanosoma brachyurum). The great parts of these organisms are typical of lacustrine zooplankton communities. The other principle species of rotifers are Brachionus budapestiensis, Keratella valga, Polyarthra trigla, Asplanchna brightwellii, Polyarthra trigla, Keratella cochlearis, Ploesoma hudsoni. The dynamics of rotifers in the reservoir varied considerably with both season and sampling sites. The
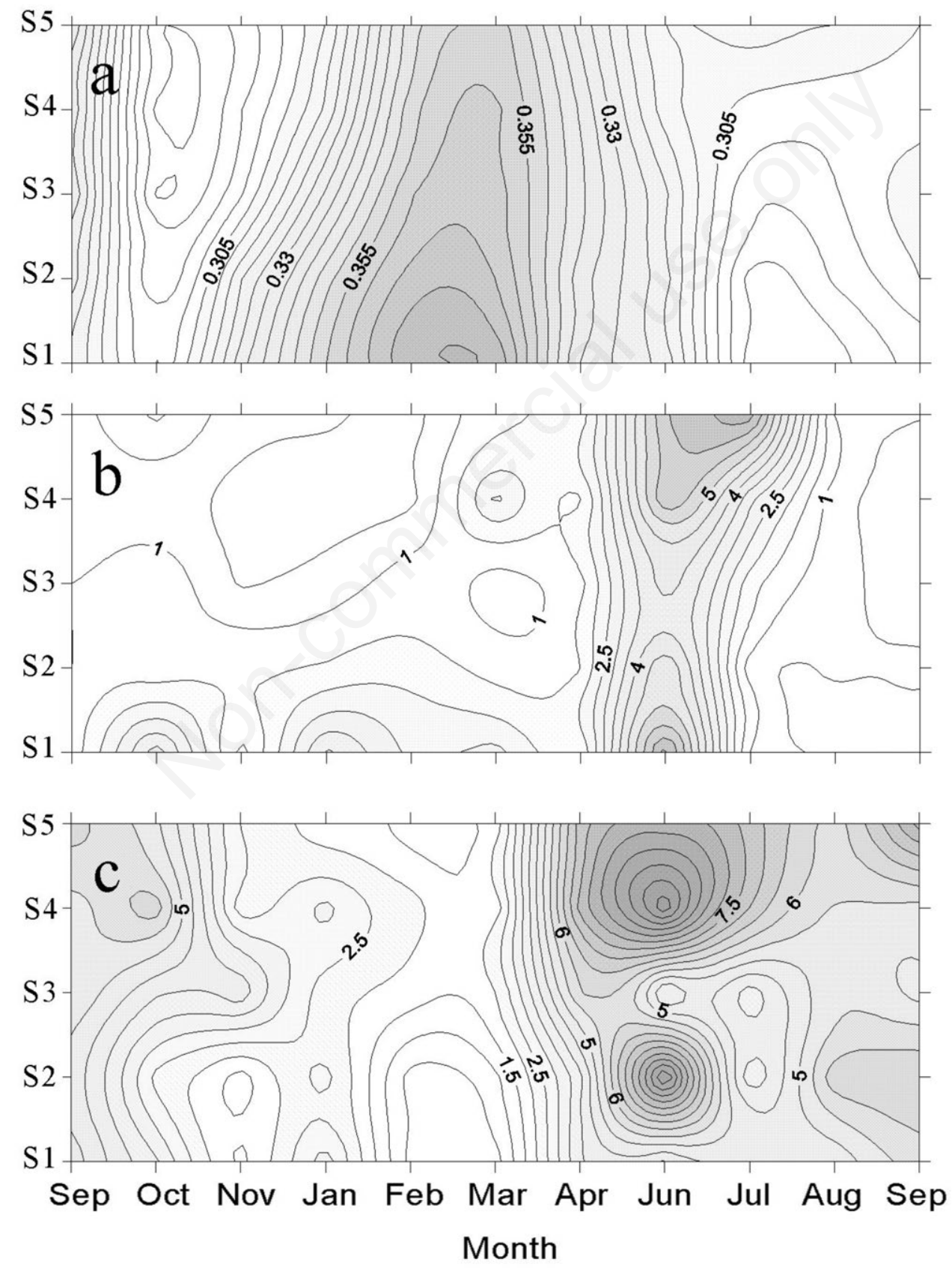

Fig. 3. Temporal and spatial variations of (a) conductivity $\left(\mathrm{mS} \mathrm{cm}^{-1}\right)$, (b) turbidity (Ntu) and (c) Chl- $a\left(\mu \mathrm{g} \mathrm{L}^{-1}\right)$. 
rotifers densities (Fig. 5a) and biomass (Fig. 5b) were lowest during the winter (November and January) and highest values were found during the summer and early autumn period (June-September). The highest biomass of rotifers appeared in August 2012 at site 5, with the Asplanchna brightwellii accounting for $98 \%$ of the ro- tifers biomass. The higher wet biomass in the June at site 4 and that in the September 2012 at site 1 was caused by the distribution of Asplanchna brightwellii (data not shown), which was much larger than other species such as Keratella cochlearis and Polyarthra trigla. As shown in Fig. 6, the Cladoceran communities showed seasonal

Tab.1. Correlation matrix showing r-values of mean data for the sampling sites.

\begin{tabular}{lccccccc}
\hline & TN & TP & Chl- $a$ & Temperature & Conductivity & DO & Turbidity \\
\hline TN & 1.00 & & & & & & \\
TP & $-0.34^{*}$ & 1.00 & & & & & \\
Chl- $a$ & $-0.45^{* *}$ & $0.40^{* *}$ & 1.00 & & & & \\
Temperature & $-0.40^{* *}$ & $0.53^{* *}$ & $0.68^{* *}$ & 1.00 & & \\
Conductivity & 0.12 & $-0.40^{* *}$ & $-0.44^{* *}$ & $-0.65^{* *}$ & 1.00 & & \\
DO & 0.22 & 0.26 & -0.07 & 0.04 & -0.26 & 1.00 & 1.00 \\
Turbidity & $-0.31^{*}$ & $0.46^{* *}$ & $0.50^{* *}$ & $0.44^{* *}$ & -0.24 & 0.25 & \\
\hline
\end{tabular}

TN, total nitrogen; TP, total phosphorus; $D O$, dissolved oxygen. $* P<0.05 ; * * P<0.01$.
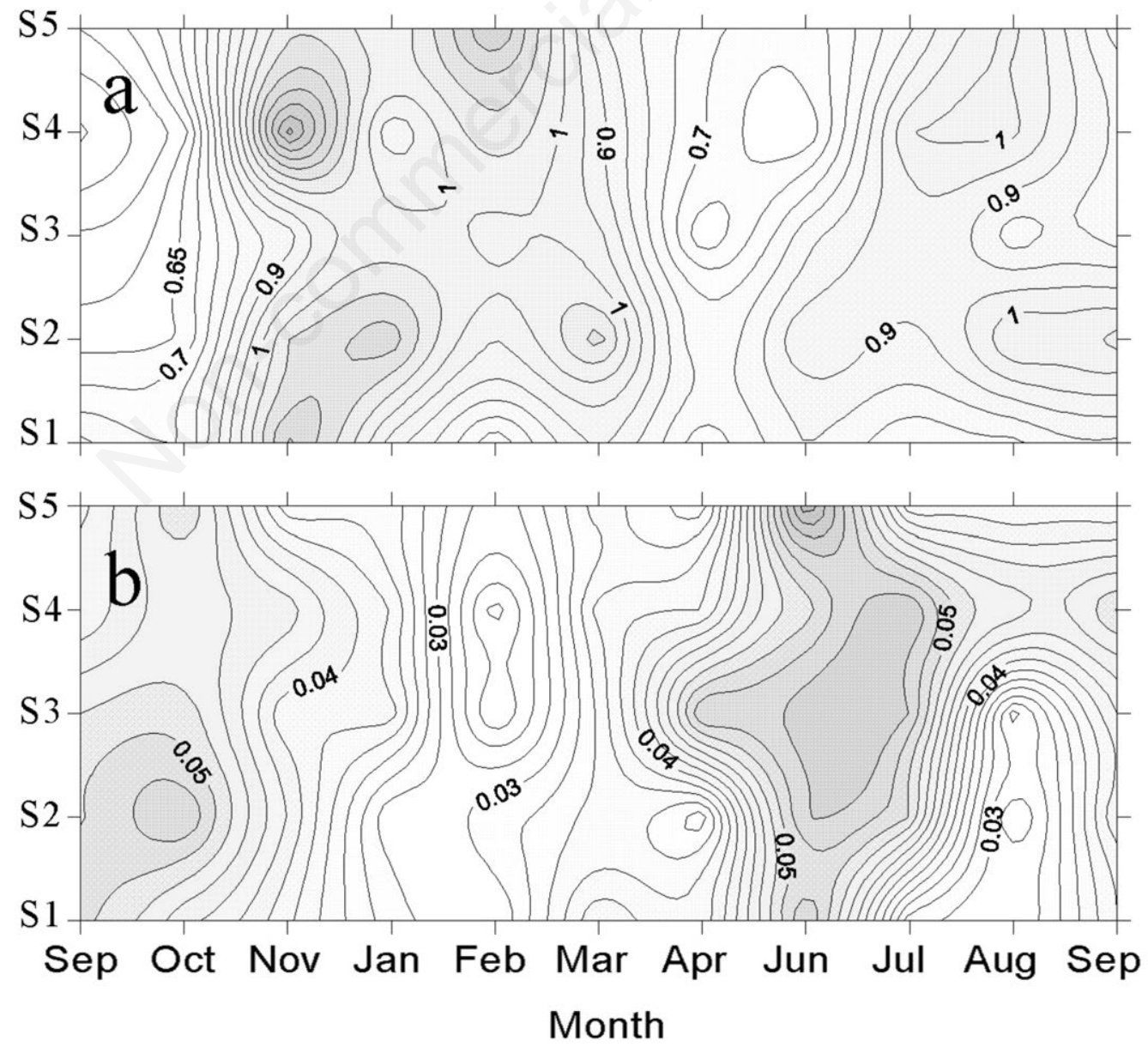

Fig. 4. Temporal and spatial variations of (a) total nitrogen $\left(\mathrm{mg} \mathrm{L}^{-1}\right)$ and (b) total phosphorus $\left(\mathrm{mg} \mathrm{L}^{-1}\right)$. 


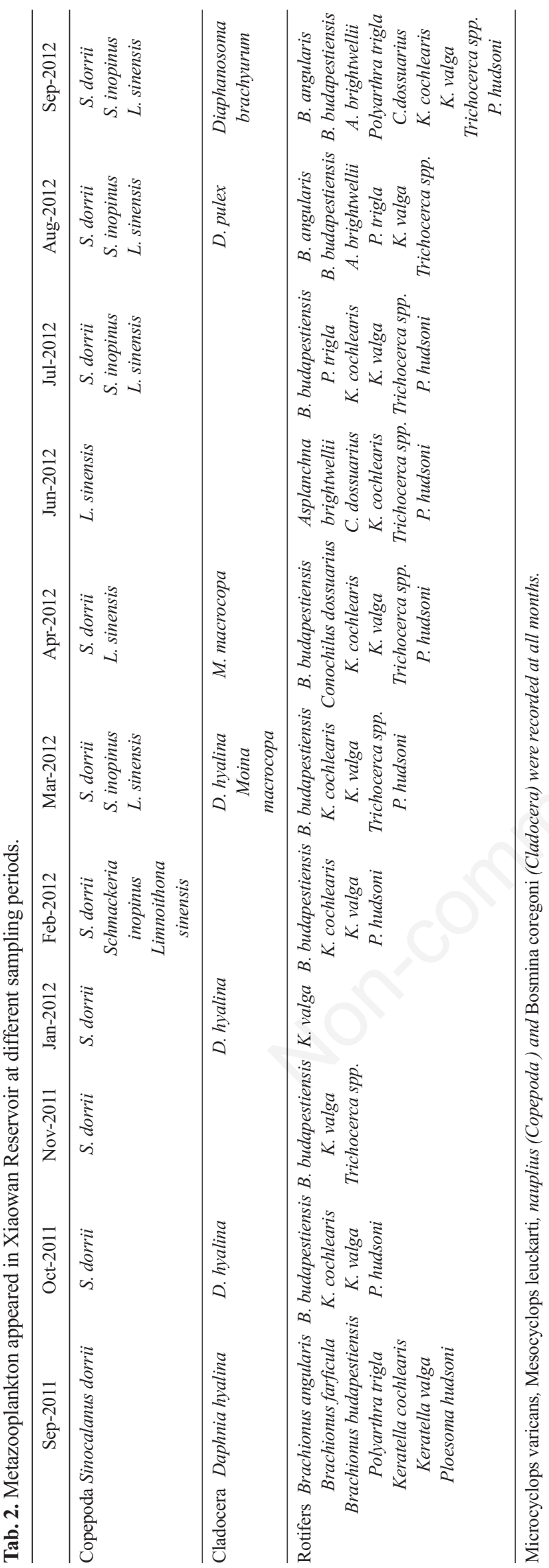

fluctuation during the sampling period both in densities (Fig. 6a) and wet biomass (Fig. 6b). The most dominant specie was Bosmina coregoni. The Daphania spp. were observed relative high number in November 2011 at site 3 , and thus accounted for the high wet biomass of Cladocera in this sample (Fig. 5b). However, the number of these large-sized Cladocera has been rarely observed in other samples. Consequently, the wet biomass of Cladocera showed a similar to its density. The average densities of the Copepoda were less than 150 ind L $\mathrm{L}^{-1}$ (Fig. 7a). During the sampling period, the numbers of nauplius accounted for about $50 \%$ of the Copepoda communities. The Copepoda also showed obvious seasonal pattern throughout the year, but did not show clear difference among the sampling sites. The highest wet biomass of Copepoda in September 2011 at site 1 due to that largesized Sinocalanus dorrii consists of $56 \%$ of the total biomass (Fig. 7b). Redundancy analysis was used to
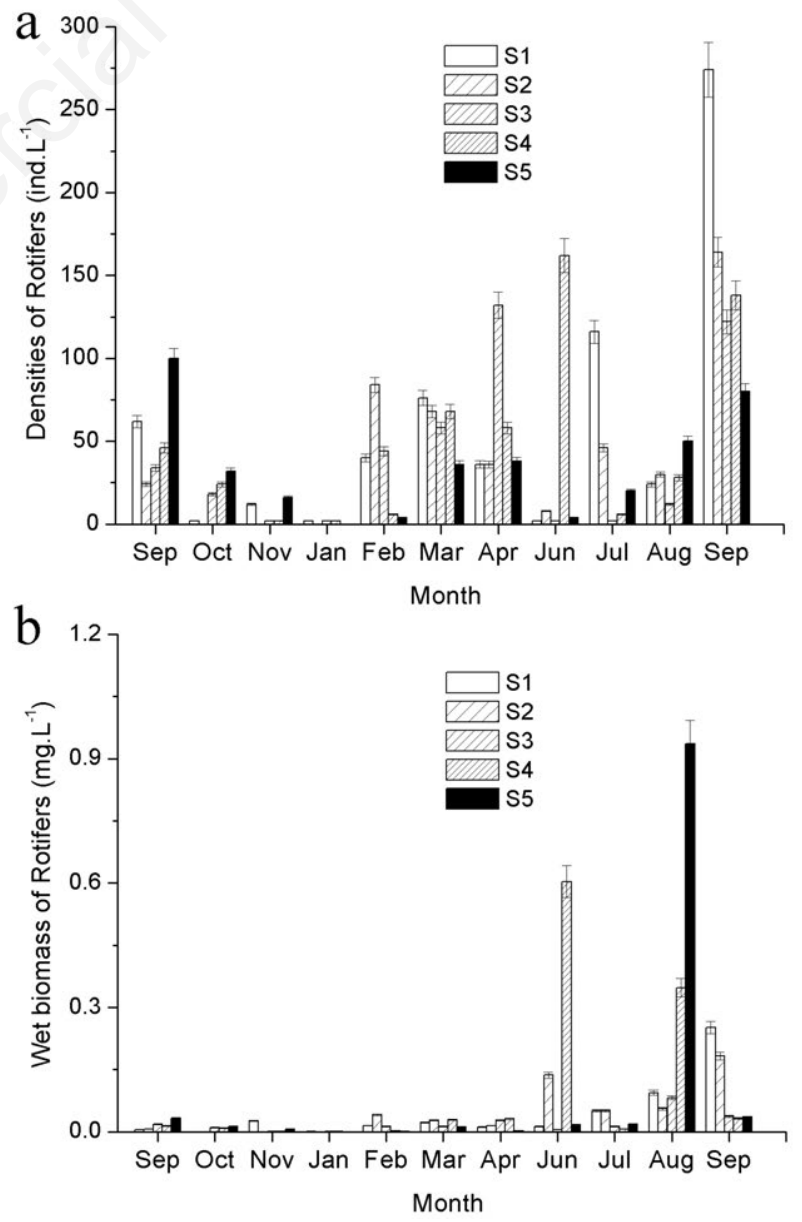

Fig. 5. Temporal variations of rotifer densities (a) and wet biomass (b) at different sites. 
ascertain the relationships between environmental variables and zooplankton communities (Fig. 8). The first ordination axis explains $49.5 \%$ while the second explains $25.6 \%$ of the total variance. The cosines of angles between environmental and zooplankton communities vectors reflect their relationships. From Fig. 8, it could be established that the temperature is highly positively related to the zooplankton communities, except for the densities of rotifers. The TP, turbidity, and Chl- $a$ also are positively related to zooplankton communities, while TN and conductivity are negatively related to zooplankton communities.

\section{DISCUSSION}

Xiaowan Reservoir is located in the middle of the upper Mekong River. There were few reports to the phytoplankton in the upper Mekong River. It is well known that temperature affects the Chl- $a$ contents and our results
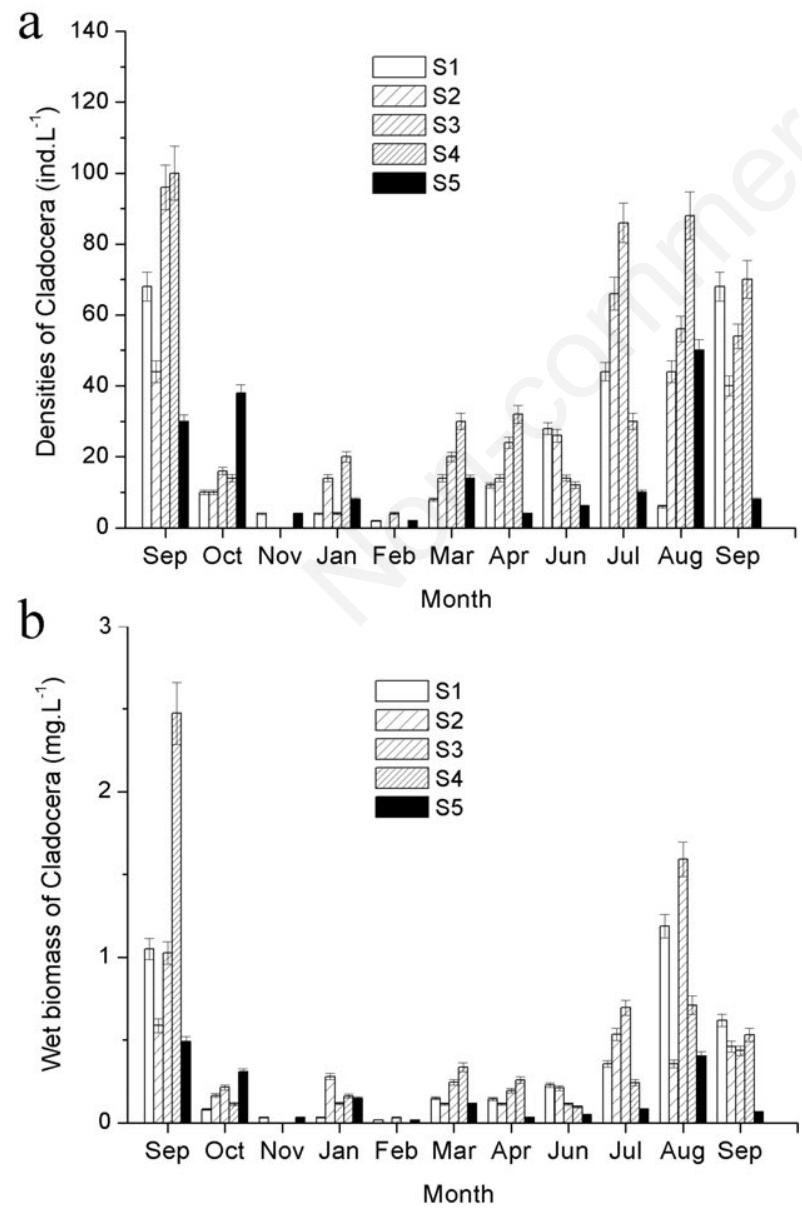

Fig. 6. Temporal variations of Cladocera densities (a) and wet biomass (b) at different sites. fit this pattern. The mean Chl- $a$ content was only about 1 $\mu \mathrm{g} \mathrm{L}^{-1}$ from January to March and was much lower than that from June to September 2013.

The conductivity was higher in winter than other period. This maybe related to the lower flow in the winter because the watershed has almost no precipitation during the dry season (November to April), and the runoff from headwater was low for similar reason. In aquatic systems, the higher flows appear to dilute dissolved material, as reflected by lower conductivity, and this finding is consistent with the results of lower Mekong River (Irvine et al., 2011; Prathumratana et al., 2008). In the Xiaowan Reservoir, the runoff generation process is supposed to create the suspended sediments since the effect of the relatively low Chl- $a$ content on turbidity (algae turbidity) was minimal (Xu et al., 2011). This speculation is supported by the variation in the DO concentration, although this concentration is not only affected by the turbulence which caused by high flow. It is not surprising that DO is
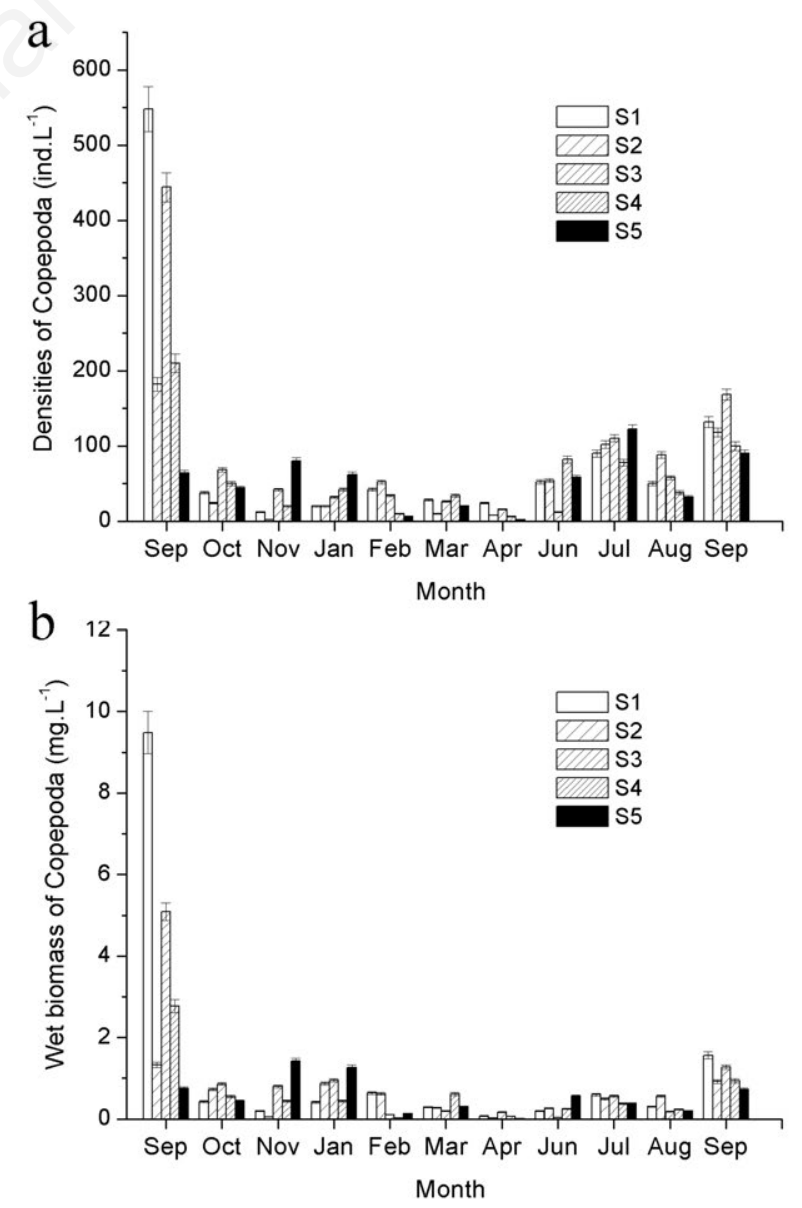

Fig. 7. Temporal variations of Copepoda densities (a) and wet biomass (b) at different sites. 
greatest during the higher flow months (June and July), as greater turbulence and freshwater runoff would serve to boost oxygen levels (Prathumratana et al., 2008). The DO curve shapes varied from month to month and showed similar patterns at different sites. Higher contents of TP in the June and July suggested that TP came mainly from surface runoff. The TN was negatively correlated with TP, which means that higher TN concentration appeared in winter. The possible explanation is that weaker nutrient demand of reduced phytoplankton growth under lower temperature conditions (Lomas and Glibert,1999). It should be mentioned that the TN and TP were relative high since the contents are sufficient to sustain high levels of phytoplankton (Guildford and Hecky, 2000).

All the zooplankton communities showed typical seasonal changes throughout the study period. It is well known that the food availability has important effects on zooplankton communities. The zooplankton numbers were greatly increased by elevated phytoplankton levels (Vanni, 1987; Lampert, 1987). Although some reports found that the rotifers were in their maximum numbers in winter (Thirupathaiah et al., 2012), the most zooplankton communities including Cladocera and Copepoda communities were lower in densities in autumn and winter (Wolfinbarger, 1999). In present study, the redundancy analysis showed the temperature played the most important role in determining of the zooplankton communities (Fig. 8). This could be explained by the combined effects of zooplankton physiological limitations and the low phytoplankton growth in winter. Compared with other eutrophic reservoirs in China (Lin et

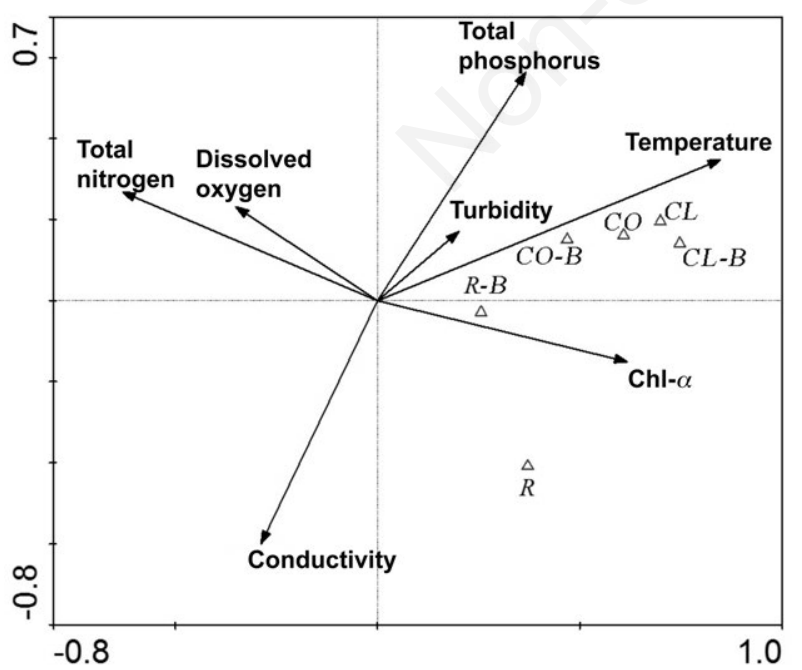

Fig. 8. RDA results of zooplankton and environmental factors for the 5 sites. R, density of rotifers; R-B, wet biomass of rotifers; CL, density of Cladocera; CL-B, wet biomass of Cladocera; $\mathrm{CO}$, density of Copepoda; $\mathrm{CO}-\mathrm{B}$, wet biomass of Copepoda. $a l ., 2003)$, the Chl- $a$ contents in the Xiaowan Reservoir during winter were still low $\left(<1 \mu \mathrm{g} \mathrm{L}^{-1}\right)$. Several authors reported that the rotifer were richest in the number of individuals in reservoir (Nogueira, 2001; Seda and Devetter, 2000). The success of limnetic rotifers in newly constructed reservoir can be related to their feeding plasticity and their opportunist characteristics (Nogueira, 2001). In newly constructed reservoirs, the rotifers in the upper regions of reservoirs were more abundant than the downstream parts (Seda and Devetter, 2000). In present study, the sampling sites located in the downstream parts and belonged to the laketype. The limnological characteristics which were similar to lakes may explain that the rotifers were not most abundant in the densities. The considerable fluctuation of the rotifers possibly due to the rapid population growth during short favorable conditions and therefore the rotifers densities were not significantly positively associated with temperature and Chl- $a$. Some Daphnia spp. were found in low abundance in the present study. This large-sized Daphnia is preferentially consumed by planktivorous fishes. It is difficult to discuss the changes of the large-sized Daphnia between the planktivorous fishes since little is known about the planktivorous fishes in the upper Mekong River. However, the dominant species of Cladocera is Bosmina coregoni, which were mainly affected by food availability (Liu et al., 2009). It was reported that the distribution of Cladocera in reservoirs associated to zones near the dam (Henry and Maricatto, 1996; Nogueira et al., 1999), which could be related to the higher turbidity in the upper regions of the reservoirs because excessive turbidity can reduce the standing stock of some Cladocera (Hart, 1986). In present study, it is difficult to find a clear spatial distribution pattern among the five sampling sites. This distribution pattern suggested that the sampling area belongs to the downstream parts of the reservoir and belonged to lake-type.

Copepoda communities showed seasonal variation in the present study. In previous studies, the Calanoida and Cyclopoida populations were usually analyzed separately since the Calanoid/Cyclopoida relation could be useful to indicate the trophic states in the reservoir (Nogueira, 2001; Tundisi et al., 1991). However, the abundance of Calanoida and Cyclopoida showed no obvious differences among the different sites (data not shown). The densities and biomass of Copepoda decreased from January to April 2012. This period was coincided with an increase of rotifers. During this period, the Copepoda mainly was consisted of nauplius, it has been pointed out that the nauplius could be found in high abundance throughout the year (Yi et al., 2010).

\section{CONCLUSIONS}

The water began to fill the reservoir on December 16, 2008 , and the water level in the reservoir began to rise. We investigated water quality parameters and metazoo- 
plankton communities in the area along the $30 \mathrm{~km}$ away from the Xiaowan dam from September 2011 to September 2012. The TN and TP levels were about 0.9 and 0.04 $\mathrm{mg} \mathrm{L}^{-1}$, respectively. The rainfall in the rainy season may have important effects on the TP contents. The typical seasonal changes of zooplankton communities were mainly driven by temperature and Chl- $a$. Our results clearly showed that this area of the reservoir belonged to laketype environment. The considerable fluctuations in the water quality parameters and zooplankton communities suggested that the water conditions were not stable. Since the TN and TP contents were relatively high in the reservoir, further studies are needed to clarify the possible changes of the aquatic ecosystems in this super reservoir in the upper Mekong River.

\section{ACKNOWLEDGMENTS}

This work was financially supported by the National Natural Science Foundation of China (41001032, U1033602, U1202232, 41101053, and 41201076). This work was also supported in part by the National Science and Technology Support Program (2013BAB06B03). We are also grateful to the staff of the Xiaowan Reservoir for the assistance during sample collection.

\section{REFERENCES}

Bigler C, Heiri O, Krskova R, Lotter AF, Sturm M, 2006. Distribution of diatoms, chironomids and cladocera in surface sediments of thirty mountain lakes in south-eastern Switzerland. Aquat. Sci. 68:154-171.

Guildford SJ, Hecky RE, 2000. Total nitrogen, total phosphorus, and nutrient limitation in lakes and oceans: is there a common relationship? Limnol. Oceanogr. 45:1213-1223.

Harris R, Wiebe P, Lenz J, Skjoldal H, Huntley M, 2000. ICES zooplankton methodology manual. Academic Press: 684 pp.

Hart RC, 1986. Zooplankton abundance, community structure and dynamics in relation to inorganic turbity, and their implications for a potential fishery in subtropical Lake Le Roux, South Africa. Freshwater Biol. 16:351-371.

He DM, Feng Y, Gan S, You WH, 2006. [The trans-boudary hydrological effects of the hydropower development in Lancang River]. [Article in Chinese with English abstract]. Chinese Sci. Bull. 51:14-20.

Henry R, Maricatto FE, 1996. Sedimentation rates of tripton in Jurumirim Reservoir (São Paulo, Brazil). Limnologica 26:15-25

Humborg C, Ittekkot V, Cociasu A, Bodungen B, 1997. Effect of Danube River dam on Black Sea biogeochemistry and ecosystem structure. Nature 386:385-388.

Irvine KN, Richey JE, Holtgrieve GW, Sarkkula J, Sampson M, 2011. Spatial and temporal variability of turbudity, dissolved oxgen, conductivity, temperature, and fluorescence in the lower Mekong River -Tonle Sap system identified using continous monitering. Int. J. River Basin Manag. 9:151-168.

Jiang X, Du N, 1979. [Fauna Sinica: Freshwater Cladocera]. [Book in Chinese]. Science Press, Beijing: 297 pp.
Jin X, Tu Q, 1990. [The standard methods for fbservation and analysis in lake eutrophication, $2^{\text {nd }} \mathrm{ed}$.] [Book in Chinese]. Chinese Environmental Science Press, Beijing, China.

Kang B, He DM, Perrett L, Wang HY, Hu WX, Deng WD, Wu YF, 2009. Fish and fisheries in the upper Mekong: current assessment of the fish commuity, threats and conservation. Rev. Fish Biol. Fisher. 19: 465- 480.

Karr JR,1991. Biological integrity: a long neglected aspect of water resource management. Ecol. Appl. 1:66-84.

Kelderman P, 1984. Sediment-water exchange in Lake Grevelingen under different environmental conditions. Netherlands J. Sea Res. 18:286-311.

Lampert W, 1987. Laboratory studies on zooplanktoncyanobacteria interactions. N. Z. J. Mar. Freshwat. Res. 21: 483-490.

Lancelot C, Staneva J, Van Eeckhout D, Beckers JM, Stanev E, 2002. Modelling the Banube-influenced North-western continental shelf of the Black Sea: II. Ecosystem response to changes in nutrient delivery by the Danube River after its damming in 1972 .Estuar. Coast. Shelf Sci. 54:473-399.

Lin QQ, Duan SS, Hu R, Han BP, 2003. Zooplankton distribution in tropical reservoirs, South China. Int. Rev. Hydrobiol. 88:602-613.

Liu GM, Liu ZW, Li YL, Chen FZ, Gu BH, Smoak JM, 2009. Effects of fish introduction and eutrophication on the cladoceran community in Lake Fuxian, a deep oligotrophic lake in southwest China. J. Paleolimnol. 42:427-435.

Lomas MW, Glibert PM, 1999. Temperature regulation of nitrate uptake: a novel hypothesis about nitrate uptake and reduction in cool-water diatoms. Limnol. Oceanogr. 44:556-572.

Nilsson C, Berggren K, 2000. Alterations of riparian ecosystems caused by river regulation. Bioscience 50: 783-792.

Nogueira MG., 2001. Zooplankton composition, dominance and abundance as indicators of environmental compartmentalization in Jurumirim Reservoir Paranapanema River), São Paulo, Brazil. Hydrobiologia 455:1-18.

Nogueira MG, Henry R, Maricatto FE, 1999. Spatial and temporal heterogeneity in the Jurumirim Reservoir, São Paulo, Brazil. Lakes Reserv. Res. Manage. 4:107-120.

Plath K, Boersma M, 2001 Mineral limitation of zooplankton: stoichiometric constraints and optimal foraging. Ecology 82:1260-1269.

Prathumratana L, Sthiannopkao S, Kim KW, 2008. The relationship of climatic and hydrologic parameters to surface water quality in the lower Mekong River. Environ. Int. 34:860-866.

Scheffer M, 1999. The effect of aquatic vegetation on turbility: how important are the filter feeders? Hydrobiologia 409: 07-316.

Schulz KL, Sterner RW, 1999. Phytoplankton phosphorus limitation and food quality for Bosmina. Limnol. Oceanogr. 44:1549-1556.

Seda J, Devetter M, 2000. Zooplankton community structure along a trophic gradient in a canyon-shaped dam reservoir. J. Plankton Res. 10:1829-1840.

Ter Braak CJF, Smilauer P, 2002. CANOCO reference manual and canoDraw for Windows User's Guide: Software for canonical community ordination (Version 4.5). Microcomputer Power, Ithaca, NY, USA.

Thirupathaiah M, Samatha Ch, Sammaish C, 2012. Analysis of water quality using physico-chemical parameters in lower 
manair reservoir of Karimnagar district, Andhra Pradesh. Int. J. Environ. Sci. 3:172-180.

Tundisi JG, Matsumura-Tundisi T, Calijuri MC, Novo EML, 1991. Comparative limnology of five reservoirs in the Middle Tietê River, S. Paulo State. Verh. Internat. Verein Limnol. 24:1489-1496.

Vanni MJ, 1987. Effects of food availability and fish predation on a zooplankton community. Ecol. Monogr. 57:61-88.

Wang HZ, Liu YD, Shen YW, Xiao BD, Liu YM, 2004. [Preliminary research on water bloom of Dinophycear in Yunnan Manwan hydropower station reservoir]. [Article in Chinese with English abstract]. Acta Hydrobiol. Sinica 28:213-215.

Wei GL, Yang ZF, Cui BS, Li B, Chen H, Bai JH, Dong SK, 2009. Impact of dam construction on water quality and water self-purification capacity of the Lancang River, China. Water Resour. Manag. 3:1763-1780.
Wolfinbarger WC, 1999. Influences of biotic and abiotic factors on seasonal succession of zooplankton in Hugo Reservoir, Oklahoma, USA. Hydrobiologia 400:13-31.

Xu YY, Cai QH, Ye L, Shao ML, 2011. Asynchrony of spring phytoplankton response to temperature driver within a spatial heterogeneity bay of Three-Gorges Reservoir, China. Limnologica 41:174-180.

Ye LL, Shi XL, Wu XD, Kong FX, 2012. Nitrate limitation and accumulation of dissolved organic carbon during a springsummer cyanobacterial bloom in Lake Taihu (China). J. Limnol. 71:71:67-71.

Yi L, Liu GQ, Xiang XG, Wang JX, Zhang YJ, 2010. [The biodiversity of crustacean zooplankton in Lake Baiyangdian].[Article in Chinese with English abstract]. J. Hydroecol. 3:38-43.

Zhang ZS, Huang XF, 1991. Research methods for freshwater plankton. Science Press, Beijing. 